\title{
CASE STUDY: SOME LESSONS FROM THE EARLY DEVELOPMENT OF NATIVE FOREST REHABILITATION AT THREE SURFACE MINE COMPLEXES IN AUSTRALIA ${ }^{1}$
}

\begin{abstract}
R.N. Humphries ${ }^{2}$
Abstract: The rehabilitation of forest and other woody vegetation ecosystems on mineral extraction sites is common place and a major post-mining land use throughout Australia. Owing to the need for government certification (under Australian Government and State legislation) for mine closure, monitoring of the establishing forests or other woody ecosystems is typically undertaken using agreed completion criteria which are predictive of rehabilitation future achievement.

The collation and review of the monitoring results for the early development of the rehabilitated forests at three surface mines provide an opportunity to identify key processes and practices that might be used to enhance the achievements in Australia and elsewhere. The monitoring results for two rehabilitation schemes in subtropical Queensland (mineral sand and coal) and one in Western Australia (bauxite) were examined.

Whilst it is evident that woody vegetation comprising several native tree and shrub species can be readily established, the resulting vegetation communities in the early development of the forest vegetation can be notably different in their composition and structure to the target and/or locally occurring native types.

It is concluded that forest structural formation in combination with species composition, are of importance in establishing the predicted trajectory of the developing forest type, ecosystem, functioning, and sustainability. Species composition is likely to influence initial forest structure and the need for intervention practices, such as thinning, that may be required to achieve the necessary structural formation and ultimately the targeted native forest types. The principles established are likely to universally apply irrespective of the mineral and climatic types examined.
\end{abstract}

Additional Key words: plant community composition, vegetation structure, bauxite, coal, mineral sand

${ }^{1}$ Oral paper presented at the 2015 National Meeting of the American Society of Mining and Reclamation, Lexington, KY Reclamation Opportunities for a Sustainable Future June 6-11, 2015. R.I. Barnhisel (Ed.) Published by ASMR, 1305 Weathervane Dr., Champaign, IL 61821.

${ }^{2}$ R. Neil Humphries, Visiting Researcher, Centre for Mined Land Rehabilitation, Sustainable Minerals Institute, University of Queensland, Brisbane, Queensland 4072, Australia. Current address, Blakemere Consultants Ltd, 1 Lower Blakemere Road, Dorchester DT1 3RZ, UK. Journal American Society of Mining and Reclamation, 2016 Volume 5, Issue 1 pp 1-27 DOI: http://doi.org/10.21000/JASMR16010001

\section{Introduction}


The rehabilitation of pre-mining native forest and other pre-mining native woody vegetation ecosystems as the intended post-mining land use is common place in Australia. Where the mining consent requires the establishment of vegetation similar to the pre-mining type, the rehabilitated areas are required to meet specific 'completion' criteria before the obligations of the mining organisations are discharged and any residual liabilities are accepted (e.g., Department of Mines and Petroleum and Environmental Protection Agency, 2011; Department of Environment and Heritage Protection, 2014). For practical reasons, where the vegetation (such as forests and woodlands) is slow to mature, the final assessments are undertaken at an early stage of forest development (often during the first 15-25 years and even within the first 1-2 years in some cases) using agreed predictive criteria, such as species composition, diversity, growth form, density, basal diameter, and height (growth). For compliance purposes, programmes of monitoring have been undertaken and as a result a wealth of data has accumulated, which in itself is a valuable source of latent knowledge to enhance rehabilitation achievement and refine the predictive criteria used.

The relative ease of establishment and rapid growth of native Acacia and Eucalyptus species readily creates woody vegetation of notable density and height within a matter of 5 to 10 years. Because of this, the mineral sands and the bauxite mining in Queensland and Western Australia are often cited as good examples of native forest rehabilitation achievement and practice (Koch and Hobbs, 2007; Smith and Nichols, 2011). However, whilst various assessments have indicated the attainment of the predictive criteria in the short term (Grant, 2006; Smith and Nichols, 2011), Gravina et al. (2011) point out that other assessment methodologies besides the current deployment of completion metrics may be required to determine the ultimate attainment of the rehabilitation objectives and any intervention actions that might be necessary.

The use of the soil-surface condition based Landscape/Ecological Functional Analysis approach (Tongway and Ludwig, 2006; Lacy, et al., 2008; Erskine, et al., 2013) and more recently the bio-condition methodology described by Neldner and Nugugi (2014) are not applicable as they do not address adequately the key ecosystem characteristics of plant community composition and structural formation (Humphries, 2016). An alternative and well-established approach based on the relevant traits of community composition, vegetation structure, and ecosystem function has been suggested and could be applied (Humphries, 2013a, 2014, and 2016). 
The purpose of this paper is to collate and review monitoring results for forest community composition and structural formation in the early development of the rehabilitated forests at three extensive mining operations in Australia. The aim is to identify key processes and practices that might enhance forest rehabilitation success in Australia and elsewhere.

\section{Method}

The rehabilitation of native forest community composition and structural formation types were examined using published and unpublished accounts, and where available, unprocessed monitoring data. Two of the three examples used were the surface mineral sands complex of mines on North Stradbroke Island and surface coal mining at the Meandu Mine near Yarraman. Both of these are located in the southeast of Queensland and have a sub-tropical climate. The third was the Huntly Mine complex, one of three active surface bauxite mines operating in the jarrah forest in the southwest of Western Australia, and has a Mediterranean climate. All three example rehabilitation sites had been restored to similar pre-mining landforms and the recovered topsoils had been replaced.

\section{Vegetation Composition}

Local Regional Ecosystem or BioCondition reference vegetation, or other target forest types or woody vegetation community data, were identified from published sources (Gravina et al., 2011; Department of Science, Information Technology, Innovation, and the Arts, 2012a, 2012b; Neldner and Ngugi, 2014) for the two mine forest rehabilitation sites studied in Queensland. This resulted in species lists for the main tree and shrub canopy layers (i.e., the ecologically dominant $\mathrm{T} 1$ and $\mathrm{T} 2$ layers as defined by Eyre et al., 2011b).

Vegetation descriptions for the ridge-top jarrah forest types affected by bauxite mining is set out by Koch (2007a) and these were used to identify relevant reference community types from data collected for the Huntley Mine and available for the period 1991 to 1994 . Reference monitoring Plot 44, surveyed in 1991 and 1994, was selected as it could be 'paired' with the selected rehabilitated Plot 148 . The threshold criterion used for identifying main species in these data sets was set at a minimum 125 stems/ha.

The selection of the rehabilitated sites depended on the necessary data being given in the publications or access to the core data collected. The Gordon Mine complex on Stradbroke Island was selected as being representative of mineral sand rehabilitation and sufficient data was 
extractable from the paper by Gravina et al. (2011), whereas this was not the case here, other sites were representative as reported by Smith and Nichols (2011). Several sources were available for the surface coal-mine complex at the Meandu Mine (Department of Science, Information Technology, Innovation, and the Arts, 2012b; Gravina et al., (Unpublished a); Neldner and Ngugi, 2014), however, the necessary vegetation community data was only reported by Gravina et al. (Unpublished b). For both the selected mineral sand and surface coal rehabilitated sites, the criteria of 100 stems/ha was used as indicators (Gravina et al., 2011 and Unpublished b) of the main tree and shrub canopy species present (i.e., the ecologically dominant).

For the Huntley Mine in Western Australia there was data for rehabilitated areas monitored between 1991 and 2005. For species composition, only the plots established in 1992 or later were considered to be representative of the reference and target forest types. Plot 148, rehabilitated in 1992, was selected and had species data available after 1 and 10 years. The threshold criteria used for identifying the main species in the data sets was set at $125 \mathrm{stems} / \mathrm{ha}$.

The species composition for the reference and rehabilitated vegetation for the three study sites are presented as comparative tables.

\section{Vegetation Structural Formation}

Structural formation classes for the Queensland Regional Ecosystem or other derived types used as reference vegetation or target types for the mineral sand and coal sites have been published by the Department of Science, Information Technology, Innovation, and the Arts (2012b) and Neldner and Ngugi (2014). The classification of Eyre et al. (2011a) was used to derive the growth form class (i.e., tree or shrub height class) and their canopy (cover) separation class.

The data provided by Gravina et al. (2011) was used to provide the height and canopy cover data (adjusted to the $100 \%$ value) for the Gordon Mine mineral sand site, from which the structural formation classes were assigned using Eyre et al. (2011a). Similar unworked data for the rehabilitated surface coal Meandu Mine (Gravina et al., Unpublished b) was used to derive the growth form class and the canopy classification, and Eyre et al. (2011a) to assign the structural formation classes.

Comparable data for height and canopy cover have not been part of the monitoring programme for the rehabilitation of jarrah forest at the Huntly Mine. However, separate plot data has been collected to derive 'site index curves' for predicting recoverable jarrah timber from rehabilitated 
areas (FORSCI, Unpublished). The curves provide estimated ranges of height from the lowest to highest yielding plots. Projective foliage cover as an estimate of canopy closure was also not monitored. This parameter was computed by Dr. Andrew Grigg of Alcoa to provide lower and upper levels which were used here to derive ranges for the canopy separation class criterion. Whilst Plot 148 had been selected as being representative of ridge top communities, it provided species lists for only 1 and 10 years of rehabilitation. Hence, the data-set from 1991 (Plot 117) was used as a surrogate to determine the subsequent forest structural development after a 15 year period.

The structural formation classes for the reference and rehabilitated vegetation for the three study sites are presented as comparative tables.

\section{$\underline{\text { Results }}$}

\section{Species Composition of Reference/Target Vegetation}

The areas affected by mineral sand mining on North Stradboke Island are extensive and consist of a patch-work of progressively rehabilitated mines (being indicative of the distribution of the mineral deposits) within the Island's ancient and stabilised dune system. The vegetation comprises extensive mosaics of native woody vegetation growth forms ranging from forest, woodland, scrub, shrub-land to heath (Stephens and Dowling, 2002; Specht, 2011; Stephens, 2011). Typically, the mining-affected areas were of high biodiversity importance and high cultural significance, such that mining is to have ceased at the Yarraman Mine in 2015 and also at the Enterprise Mine in 2019, should its lease not be renewed. The aim of the rehabilitation was to re-establish native woody vegetation as close to the reference types as possible as was set out and agreed in 2006 (Smith and Nichols, 2011).

Harwood and Corbett (Unpublished a) identified five target vegetation types typical of those parts of the Island vegetation affected by the mining. These were: a 'young dune open-forest type; a young dune (Yarraman) open-forest; Eucalyptus pilularis open-forest on parabolic high dunes (equivalent to Queensland Regional Ecosystem RE 12.2.8, Department of Science, Information Technology, Innovation, and the Arts, 2012a); Eucalyptus planchoniana - Banksia aemula low open-woodland on dunes and sand plains (equivalent to RE 12.2.10); and Banksia aemula Eucalyptus racemosa heath on dunes (equivalent to RE 12.2.9). For the sites surveyed by Smith and Nichols (2011), three particular forest/woodland community types were identified by Stephens 
and Dowling (2002) as being appropriate target end-point types for rehabilitation. These were Corymbia intermedia open-forest (equivalent to RE 12.2.5), Eucalyptus racemosa woodland/open-forest (equivalent to RE 12.2.6), and Eucalyptus piluaris woodland (equivalent to RE 12.2.8). For the Gordon Mine surveyed by Gravina et al. (2011), the local native community target types were largely the same as referred to by Smith and Nichols, with the addition of a fourth, Eucalyptus planchoniana a low shrubby open-forest (equivalent to RE 12.2.10).

The surface mining of coal at the Meandu Mine, Tarong, near Yarraman in the southeast of Queensland has been established for some 20-30 years over which progressive forest rehabilitation has taken place. Whilst locally there are areas of native forests of high biodiversity and plantations important for timber production, the surface mining has mainly been in areas of former Eucalyptus forest cleared for cattle ranching, thereby leaving only degraded remnants of forest that are affected (Gravina et al., Unpublished a). The objective of post-mining rehabilitated land use was to establish a sustainable forest or woodland ecosystem using native species, with the inclusion of tree species having a potential for timber production, but not necessarily the replication of local native forest types (Gravina et al., Unpublished a).

Three 'remnant' Eucalypt types were suggested as the rehabilitation target, these were: Eucalyptus creba - Corymbia spp - Eucalyptus tereticornis - Angophora spp woodland to openforest (approximate to Queensland RE12.9-10.18); Eucalyptus creba - Eucalyptus moluccana grassy woodland to open-forest (approximate to RE12.11.4); and Eucalyptus creba-Angophora woodland (approximate to RE 12.9-10.7). For the same location, Neldner and Ngugi (2014) identified three local Regional Ecosystem types with two of these corresponding to those identified by Gravina et al. (Unpublished a); these were RE12.9-10.7 and RE 12.9-10.18, with an additional type Eucalyptus crebra sparse woodland, RE12.11.7.

The mining of bauxite at the Huntly Mine is located on the extensively forested upland ridges (bearing the mineral), and is situated behind the coastal strip of Western Australia (Gardner and Bell, 2007). The area of mining is extensive and long established, and comprises a patch-work of mined and progressively rehabilitated land within an unmined forest matrix (Koch, 2007a).

The jarrah forest in Western Australia is a dry sclerophyll open forest to woodland of unusual composition being dominated by a mixture of two eucalypt species, jarrah (Eucalyptus marginata) and marri (Corymbia calophylla), and noted for its varied plant assemblages and diverse flora, 
particularly in its understory (Koch, 2007b). The forest with its variable landscape of ridges and small valleys with swamps and ephemeral streams is regarded as being of the highest international biodiversity importance (Hopper, 2009). Koch (2007b) summarises the mining impacted community types and their key indicators as: ridge top/upper slope E. marginata - C. calophylla forest with Pteridium esculentum and Leucopogon verticillatus; mid- to upper-slope forest of $E$. marginata - C. calophylla-Banksia grandis; and mid- to lower-slope forest of E. marginata - C. calophylla - Allocasuarina fraseriana, with A. fraseriana as a second story.

\section{Species Composition of Rehabilitated Forests}

Smith and Nichols (2011) in their 2006 assessment of rehabilitation of mineral sand mines on North Stradbroke Island used a time-based (chrono-sequence) approach to assess the achievements and compliance with the predictive criteria. The time-based series comprised three sites spanning the period 1990 to 2002 to give examples of rehabilitation of between 4 and 16 years in age. Unfortunately, they report only aggregated growth-form data, so no conclusions can be drawn as to the trend towards the target forest/woodland composition and structure per se. In another study for the Gordon Mine, time sequence data was available for rehabilitated forest established between 1987 and 2000 (aged 8, 10, 15, and 20 years post rehabilitation). Here, Gravina et al. (2011) report that a range of native woody species have been successfully established at the Gordon Mine, including a number that are components of the local vegetation types (see Table 1 on next page).

From the narratives of Gravina et al. (2011) and Smith and Nichols (2011), the rehabilitation achievement at the Gordon Mine can be reasonably assumed to be a reflection of the species sown and/or planted. After 10 to 20 years, the vegetation established comprised a mixture of some of the woody species associated with the target types, but others which were not. This applies to both the older Plot G20 and the later planting/seeding specification of the younger Plot G10. Consequently, the later schemes were altered to reduce or exclude the seeding of Allocasuarina species and Acacia concurrens, and the inclusion of a greater range of shrub and ground-cover species (Smith and Nichols, 2011). It is considered that the modified seeding and planting practices has resulted in an increase in similarity between the rehabilitated and target communities on account of the number of typical dominant species occurring (Gravina et al., 2011). The effect of their inclusion is illustrated in the distinct separation between the individual target community composition and those established on the mine site (Table 1). Any similarity to the reference/target types appears to be loose because the rehabilitated areas contained only some of the main canopy 
species, and besides, there was very poor representation of the small shrubs in the lower shrub layer, and ferns and graminoids in the ground layer compared with the target communities (Gravina et al., 2011).

Table 1. Main Tree and Shrub Canopy Species for Reference Forest and Rehabilitated Areas G10 and G20 at the Gordon Mineral Sand Mine.

\begin{tabular}{|c|c|c|c|c|}
\hline Tree \& Shrub Species & $\begin{array}{l}\text { Regional } \\
\text { Reference Site: } \\
\text { Eucalyptus } \\
\text { pilularis open- } \\
\text { forest / open- } \\
\text { woodland (RE } \\
\text { 12.2.8)\# }\end{array}$ & $\begin{array}{l}\text { Local Reference } \\
\text { Site: R4pla - Malle } \\
\text { Eucalyptus } \\
\text { planchoniana low } \\
\text { open-forest / open- } \\
\text { woodland* }\end{array}$ & $\begin{array}{l}\text { Plot G10 } \\
-10 \\
\text { years } \\
\text { old }^{*}\end{array}$ & $\begin{array}{l}\text { Plot G20 } \\
-20 \text { years } \\
\text { old* }\end{array}$ \\
\hline Angophora leiocarpa & + & & & \\
\hline Banksia aemula & + & + & & \\
\hline Banksia serrata & + & & & \\
\hline Eucalyptus pilularis & + & & + & + \\
\hline Eucalyptus planchoniana & + & + & + & \\
\hline Eucalyptus racemosa & + & & + & \\
\hline Lophostemon confertus & + & & & \\
\hline Corymbia gummifera & & + & + & \\
\hline Allocasuarina littoralis & & & + & + \\
\hline Allocasuarina torulosa & & & + & \\
\hline Corymbia intermedia & & & + & \\
\hline
\end{tabular}

Sources - \# Department of Science, Information Technology, Innovation, and the Arts, (2012a)

*Gravina et al., (2011), Table 2.

Overall, the same trends in species composition of the rehabilitated communities were recorded at the Meandu surface coal mine in the southeast of Queensland (Gravina et al., Unpublished b; Neldner and Ngugi, 2014). They report that the target of establishing a range of native woody species has been successfully achieved, including a number of Eucalyptus and Corymbia timber species (Table 2). The composition of the woody vegetation established reflected those species sown/planted and comprised a mixture of some woody species associated with the target types and others which were not.

Table 2. Main Tree and Shrub Canopy Species for Reference Forest and Rehabilitated Areas SW6 and K2.2 at the Meandu Surface Coal Mine. 


\begin{tabular}{|c|c|c|c|c|}
\hline Tree and Shrub Species & $\begin{array}{l}\text { Example Reference Site: } \\
\text { Eucalyptus - Corymbia - } \\
\text { Angophora woodland/open- } \\
\text { forest (RE 12.9-10.18)\# }\end{array}$ & $\begin{array}{l}\text { Bio- } \\
\text { Condition } \\
\text { Reference } \\
\text { Site } \sim\end{array}$ & $\begin{array}{l}\text { SW6 - } \\
6 \text { years } \\
\text { old* }\end{array}$ & $\begin{array}{l}\text { K2.2- } \\
10 \text { years } \\
\text { old }^{*}\end{array}$ \\
\hline Acaccia blakei & + & + & + & + \\
\hline Acacia disparrima var & + & + & & \\
\hline Acacia leiocalyx & + & + & & + \\
\hline Alphitonia excelsa & + & + & & \\
\hline Angophora leiocarpa & + & + & & \\
\hline Eucalyptus creba & + & + & & + \\
\hline Eucalyptus longirostrata & + & + & & \\
\hline Jacksonia scoperia & + & + & & \\
\hline Cassinia laevis & & + & + & \\
\hline Corymbia intermedia & & + & & \\
\hline Dodonaea triangularis & & + & & + \\
\hline Acacia aulacocarpa & & & & + \\
\hline Acacia fimbriata & & & + & + \\
\hline Acacia glaucocarpa & & & + & + \\
\hline Acacia neriifolia & & & + & \\
\hline Corymbia citriodora ssp & & & + & + \\
\hline Eucalyptus moluccana & & & & + \\
\hline Lantana camara & & & & + \\
\hline
\end{tabular}

Sources - \# Department of Science, Information Technology, Innovation, and the Arts, (2012a) $\sim$ Neldner and Ngugi, (2014) *Gravina et al., (Unpublished b)

As for the previous two sites, a range of native species had established in the Huntley Mine rehabilitation example Plot 148 with a loose association between the rehabilitated area and the reference site owing to a number of atypical species being present, particularly Acacia shrub species (Table 3). Plot 148 also exhibited a shift in the composition of the main canopy species between 1 and 10 years and in particular an increase in Acacia species. However, the two characteristic jarrah (Eucalyptus marginata) and marri (Corymbia calophylla) had established as main canopy tree species.

Table 3. Main Tree and Shrub Canopy Species for Reference Forest and Rehabilitated Plot 148 at the Huntly Bauxite Mine. 
JASMR, 2016 Volume 5 Issue 1

\begin{tabular}{|c|c|c|c|}
\hline Tree and Shrub Species & $\begin{array}{l}\text { Reference Plot } 44 \\
\text { (aggregate of } 1991 \& \\
1994 \text { records) }\end{array}$ & $\begin{array}{l}\text { Rehabilitated Plot } \\
148 \text {-1 year old }\end{array}$ & $\begin{array}{l}\text { Rehabilitated Plot } \\
148 \text { - } 10 \text { years old }\end{array}$ \\
\hline Acacia drummondii & + & + & + \\
\hline Acacia pulchella & + & + & + \\
\hline Banksia grandis & + & & \\
\hline Billardiera variifolia & + & & \\
\hline Bossiaea aquifolium & + & + & + \\
\hline Corymbia calophylla & + & + & + \\
\hline Eucalyptus marginata & + & + & + \\
\hline Leucopogon capitellatus & + & & \\
\hline Leucopogon verticillatus & + & & \\
\hline Persoonia longifolia & + & & \\
\hline Trymalium ledifolium & + & + & + \\
\hline Acacia extensa & & + & + \\
\hline Acacia lateriticola & & + & + \\
\hline Acacia urophylla & & + & \\
\hline Bossiaea ornata & & + & + \\
\hline Mirbelia dilatata & & + & \\
\hline Sphaerolobium medium & & + & \\
\hline Acacia alata & & & + \\
\hline Acacia horridula & & & + \\
\hline Billardiera fusiformis & & & + \\
\hline
\end{tabular}

$\underline{\text { Structural Formation of Reference/Target and Rehabilitated Forests }}$

The structural formation class criteria set out by Eyre et al. (2011a) is used in the Queensland Regional Ecosystem descriptions (Department of Science, Information Technology, Innovation, and the Arts, 2012a). Using this, the structural traits for the target forest vegetation types on North Stradbroke Island are set out in Table 4.

Table 4. Structural Traits for Target Vegetation Types on North Stradbroke Island.

\begin{tabular}{|l|l|l|l|l|}
\hline $\begin{array}{l}\text { Target } \\
\text { Vegetation } \\
\text { Community }\end{array}$ & $\begin{array}{l}\text { Regional } \\
\text { Ecosystem } \\
\text { Reference (RE)* }\end{array}$ & $\begin{array}{l}\text { Growth Form } \\
\text { Class }^{1}\end{array}$ & $\begin{array}{l}\text { Canopy } \\
\text { Separation Class }\end{array}$ & $\begin{array}{l}\text { Structural } \\
\text { Formation Class }\end{array}$ \\
\hline
\end{tabular}


JASMR, 2016 Volume 5 Issue 1

\begin{tabular}{|l|l|l|l|l|}
\hline $\begin{array}{l}\text { Corymbia } \\
\text { intermedia }\end{array}$ & 12.2 .5 & Trees 10-30m & Mid-dense & Open-forest \\
\hline $\begin{array}{l}\text { Eucalyptus } \\
\text { planchoniana }\end{array}$ & 12.2 .6 & Trees 10-30m & $\begin{array}{l}\text { Sparse - Mid- } \\
\text { dense }\end{array}$ & $\begin{array}{l}\text { Woodland - } \\
\text { Open-forest }\end{array}$ \\
\hline $\begin{array}{l}\text { Eucalyptus } \\
\text { pilularis }\end{array}$ & 12.2 .8 & Trees 10-30m & Sparse & Woodland \\
\hline $\begin{array}{l}\text { Eucalyptus } \\
\text { planchoniana - } \\
\text { Banksia aemula }\end{array}$ & 12.2 .10 & Trees <10m & Mid-dense & Low open-forest \\
\hline
\end{tabular}

Sources - * Department of Science, Information Technology, Innovation, and the Arts, (2012a)

${ }^{1}$ Eyre et al., (2011a)

Comparing the data provided by Gravina et al. (2011) with the structural formation class of Eyre et al. (2011a) it can be seen that within the time since rehabilitation a closed-scrub type of vegetation had established at the Gordon Mine site (Table 5). In contrast, the mature native target vegetation types have a taller range of structural forms within each community ranging from closed to open types of woodland to forest. Whilst the end-point formation type achieved by the rehabilitated stands will need a longer period of time in the growth and maturation of the tree species, the rehabilitated areas reported by Gravina et al. (2011) and Smith and Nichols (2011) have much higher stem densities and comprise a more closed vegetation than their native Regional Ecosystem counterparts.

Gravina et al. (Unpublished b) also adopted a time sequence approach to describing vegetation performance of rehabilitated areas at the Meandu Mine rehabilitated 1995 to 2006 (aged 5 to 16 years post rehabilitation at the time of monitoring). Their report usefully contains a compilation of the raw data collected, as well as site descriptions and photographs. This enabled further examination and interpretation and particularly in respect to the traits reflecting forest structural development relative to those of the target types (Table 6).

Table 5. Derived Structural Traits for Rehabilitated Forest Vegetation at the Gordon Mineral Sand Mine.

\begin{tabular}{|l|l|l|l|l|l|}
\hline $\begin{array}{l}\text { Area } \\
\text { Code }\end{array}$ & $\begin{array}{l}\text { Year } \\
\text { sown / } \\
\text { planted }\end{array}$ & $\begin{array}{l}\text { Age } \\
\text { (years })\end{array}$ & $\begin{array}{l}\text { Growth } \\
\text { Form Class }^{1}\end{array}$ & $\begin{array}{l}\text { Canopy Separation } \\
\text { Class }^{2}\end{array}$ & $\begin{array}{l}\text { Structural } \\
\text { Formation Class }^{3}\end{array}$ \\
\hline G8 & 1998 & 8 & Shrubs 2-8m & sparse & Tall shrubland \\
\hline
\end{tabular}


JASMR, 2016 Volume 5 Issue 1

\begin{tabular}{|l|l|l|l|l|l|}
\hline G10 & 1996 & 10 & Shrubs 2-8m & Mid-dense - dense & $\begin{array}{l}\text { Open scrub / Closed } \\
\text { scrub }\end{array}$ \\
\hline G15 & 1991 & 15 & Shrubs 2-8m & Mid-dense - dense & $\begin{array}{l}\text { Open scrub / Closed } \\
\text { scrub }\end{array}$ \\
\hline G20 & 1986 & 20 & Shrubs 2-8m & dense & Closed scrub \\
\hline
\end{tabular}

Sources $-{ }^{1}$ Gravina et al. (2011), Table $2{ }^{2}$ Gravina et al. (2011), Table $1,{ }^{3}$ Eyre et al. (2011a)

Table 6: Structural Traits for Target Vegetation Types at the Meandu Surface Coal Mine

\begin{tabular}{|l|l|l|l|l|}
\hline $\begin{array}{l}\text { Target Vegetation } \\
\text { Community }\end{array}$ & $\begin{array}{l}\text { Regional } \\
\text { Ecosystem } \\
\text { Reference } \\
(\mathrm{RE}) *\end{array}$ & $\begin{array}{l}\text { Growth Form } \\
\text { Class }\end{array}$ & $\begin{array}{l}\text { Canopy } \\
\text { Separation Class }\end{array}$ & $\begin{array}{l}\text { Structural } \\
\text { Formation Class }^{1}\end{array}$ \\
\hline $\begin{array}{l}\text { Eucalyptus creba }- \\
\text { Angophora spp }\end{array}$ & $12.9-10.7$ & Trees 10-30m & Sparse & Woodland \\
\hline $\begin{array}{l}\text { Eucalyptus creba }- \\
\text { Corymbia spp }- \\
\text { Eucalyptus } \\
\text { tereticornis }- \\
\text { Angophora spp }\end{array}$ & $12.9-10-18$ & Trees 10-30m & $\begin{array}{l}\text { Sparse - Mid- } \\
\text { dense }\end{array}$ & $\begin{array}{l}\text { Woodland - } \\
\text { Open-forest }\end{array}$ \\
\hline $\begin{array}{l}\text { Eucalyptus creba }- \\
\text { Eucalyptus } \\
\text { moluccana }\end{array}$ & 12.11 .4 & Trees 10-30m & $\begin{array}{l}\text { Sparse - Mid- } \\
\text { dense }\end{array}$ & $\begin{array}{l}\text { Woodland - } \\
\text { Open-forest }\end{array}$ \\
\hline Eucalyptus crebra & 12.11 .7 & Trees 10-30m & Sparse & Woodland \\
\hline
\end{tabular}

Sources - * Department of Science, Information Technology, Innovation, and the Arts, 2012a.

${ }^{1}$ Eyre et al. (2011a)

The application of the structural formation classification (Eyre et al., 2011a) indicated that in the absence of tree growth generally exceeding 10m, none of the areas rehabilitated in 1999/2000 have so far achieved the target forest or woodland structure (Table 7).

Table 7. Derived Structural Traits for Rehabilitated Forest Vegetation at the Meandu Surface Coal Mine.

\begin{tabular}{|l|l|l|l|l|l|}
\hline $\begin{array}{l}\text { Area } \\
\text { Code }\end{array}$ & $\begin{array}{l}\text { Year } \\
\text { sown / } \\
\text { planted }\end{array}$ & $\begin{array}{l}\text { Age } \\
\text { (years) }\end{array}$ & $\begin{array}{l}\text { Growth } \\
\text { Form Class }^{1}\end{array}$ & $\begin{array}{l}\text { Canopy } \\
\text { Separation Class }\end{array}$ & Formation Class $^{2}$ \\
\hline kun & 2006 & 5 & Shrubs 2-8m & $\begin{array}{l}\text { Sparse - Mid- } \\
\text { dense }\end{array}$ & $\begin{array}{l}\text { Tall shrubland / open } \\
\text { scrub }\end{array}$ \\
\hline
\end{tabular}


JASMR, 2016 Volume 5 Issue 1

\begin{tabular}{|l|l|l|l|l|l|}
\hline Sw7 & 2005 & 6 & Shrubs 2-8m & Mid-dense & Open scrub \\
\hline mag & 2005 & 6 & Shrubs 2-8m & $\begin{array}{l}\text { Mid-dense - } \\
\text { dense }\end{array}$ & $\begin{array}{l}\text { Open scrub / closed } \\
\text { scrub }\end{array}$ \\
\hline Nw4 & 2005 & 6 & Shrubs 2-8m & Mid-dense & Open scrub \\
\hline K2.5 & 2005 & 6 & Shrubs 2-8m & $\begin{array}{l}\text { Mid-dense - } \\
\text { dense }\end{array}$ & $\begin{array}{l}\text { Open scrub / closed } \\
\text { scrub }\end{array}$ \\
\hline Sw6 & 2004 & 7 & Shrubs 2-8m & Mid-dense & Open scrub \\
\hline K2.2 & 2000 & 11 & $<10 m$ trees & Mid-dense & Low open-forest \\
\hline Sw3 & 1999 & 12 & $<10 m$ trees & Mid-dense & Low open-forest \\
\hline Sw2 & 1997 & 14 & Shrubs 2-8m & $\begin{array}{l}\text { Mid-dense - } \\
\text { dense }\end{array}$ & $\begin{array}{l}\text { Open scrub / closed } \\
\text { scrub }\end{array}$ \\
\hline Nw95 & 1995 & 16 & Shrubs 2-8m & Mid-dense & Open scrub \\
\hline
\end{tabular}

Source $-{ }^{1}$ Gravina et al. (Unpublished b) ${ }^{2}$ Eyre et al. (2011a)

The timber Eucalyptus and Corymbia species were present in the canopy and attainment of a forest or woodland form is likely to be a matter of more time and reliance on the growth of the Eucalyptus and Corymbia tall-tree layer species. In contrast, some of the older rehabilitated areas at Meandu Mine exhibited less dominance by tall shrub species as they reached the end of their life span with a result of a more open, or low open-forest structure appearing to develop. Whereas, the youngest areas reported (sown/planted in 2006) corresponded to a tall shrubland formation with a low shrub layer and well developed ground layer.

Notably, the ground layer in the closed-forest structural formation at the Meandu Mine was absent or very sparse, and the low-shrub layer was generally absent under the dense canopy, whereas the more open canopy of the open-forest like formation had areas with moderate groundlayer cover and a low-shrub layer. In all cases, the shrub layer was dominated by tall shrub and tree canopy species. A feature of the pre-1999 schemes was the co-dominance of Acacia species and the invasive weed vine species Lantana camara. In contrast, the post-2000 areas of 6-7 years old exhibited some stratification with shrub and ground layers and separated canopies of incipient Eucalyptus tree layer growth. 
The tall-forest structural formation of the reference ridge-top/upper-slope jarrah forest type is given in Table 8 .

Table 8. Derived Structural Traits for Target Vegetation Types at the Huntly Bauxite Mine.

\begin{tabular}{|c|c|c|c|c|}
\hline $\begin{array}{l}\text { Target Vegetation } \\
\text { Community } 1\end{array}$ & $\begin{array}{l}\text { Reference } \\
\text { Type1 }\end{array}$ & $\begin{array}{l}\text { Growth Form } \\
\text { Class2 }\end{array}$ & $\begin{array}{l}\text { Canopy } \\
\text { Separation } \\
\text { Class2 }\end{array}$ & $\begin{array}{l}\text { Structural } \\
\text { Formation Class } 2\end{array}$ \\
\hline $\begin{array}{l}\text { E. marginata }-C \text {. } \\
\text { calophylla forest } \\
\text { with Pteridium } \\
\text { esculentum }\end{array}$ & $\begin{array}{l}\mathrm{T} \text { - ridge } \\
\text { top/upper slope }\end{array}$ & Trees $>30 \mathrm{~m}$ & $\begin{array}{l}\text { Mid-dense to } \\
\text { dense }\end{array}$ & $\begin{array}{l}\text { Tall open forest / } \\
\text { tall closed forest }\end{array}$ \\
\hline $\begin{array}{l}\text { E. marginata }-C . \\
\text { calophylla - } \\
\text { Banksia grandis }\end{array}$ & $\begin{array}{l}\mathrm{S} \text { - mid- to } \\
\text { upper-slope }\end{array}$ & Trees $>30 \mathrm{~m}$ & $\begin{array}{l}\text { Mid-dense to } \\
\text { dense }\end{array}$ & $\begin{array}{l}\text { Tall open forest / } \\
\text { tall closed forest }\end{array}$ \\
\hline $\begin{array}{l}\text { E. marginata }-C . \\
\text { calophylla }- \\
\text { Allocasuarina } \\
\text { fraseriana }\end{array}$ & $\begin{array}{l}\mathrm{P} \text { - mid- to } \\
\text { lower-slope }\end{array}$ & Trees $>30 \mathrm{~m}$ & $\begin{array}{l}\text { Mid-dense to } \\
\text { dense }\end{array}$ & $\begin{array}{l}\text { Tall open forest / } \\
\text { tall closed forest }\end{array}$ \\
\hline
\end{tabular}

Source $-{ }^{1}$ Koch, (2007b) ${ }^{2}$ Eyre et al. (2011a)

For the rehabilitated area containing Plot 117, the derived structural formation classes in Table 9 indicate that the rehabilitated forest at Huntly Mine over a 15 year period is developing towards a forest-like structure. In contrast to the other two rehabilitation examples, there was no indication that the rehabilitated area had stalled at the scrub stage despite a number of species Acacia being part of the main canopy assemblages. This is probably attributable to the practice of using lower seeding/planting densities than at the other examples. Hence, the rehabilitation might be expected, with further growth, to achieve an open/closed tall forest structure similar to the target types. 
Table 9. Derived Structural Traits for Rehabilitated Forest Vegetation at the Huntly Bauxite Mine.

\begin{tabular}{|l|l|l|l|l|l|}
\hline Area Code & $\begin{array}{l}\text { Year sown / } \\
\text { planted }\end{array}$ & Age (years) & $\begin{array}{l}\text { Growth } \\
\text { Form Class }\end{array}$ & $\begin{array}{l}\text { Canopy } \\
\text { Separation } \\
\text { Class }^{2}\end{array}$ & $\begin{array}{l}\text { Structural } \\
\text { Formation Class }\end{array}$ \\
\hline 117 & 1991 & 1 & Shrubs $<1 \mathrm{~m}$ & Very sparse & $\begin{array}{l}\text { Dwarf open } \\
\text { shrubland - open } \\
\text { shrubland }\end{array}$ \\
\hline 117 & 1991 & 10 & $\begin{array}{l}\text { Trees range } \\
<10 \mathrm{~m}-10- \\
30 \mathrm{~m}\end{array}$ & $\begin{array}{l}\text { Sparse } \\
\text { wow woodland - }\end{array}$ \\
\hline 117 & 1991 & 15 & $\begin{array}{l}\text { Trees 10- } \\
30 \mathrm{~m}\end{array}$ & $\begin{array}{l}\text { Sparse - } \\
\text { Mid-dense }\end{array}$ & $\begin{array}{l}\text { Woodland - open } \\
\text { forest }\end{array}$ \\
\hline
\end{tabular}

Source $-{ }^{1}$ FORSCI, (Unpublished) ${ }^{2}$ A. Grigg (personal communication), ${ }^{3}$ Eyre et al., (2011a)

\section{$\underline{\text { Discussion }}$}

It should be noted that the following is drawn from rehabilitation schemes established one or two decades ago and may need to be tempered by subsequent changes in practice as knowledge and experience has accumulated. For example, significant changes in species composition and seeding and/or planting density took place in the rehabilitation of mineral sands at North Stradbroke Island in 1987 and in 2002 at the Meandu surface coal mine. Similar changes in the refinement of practices at the Huntly bauxite mine have been an ongoing process since the early 1990s. This has included particular attention to sowing and planting densities to avoid creating dense stands that excluded ground and small shrub flora, and perfecting methods of introducing recalcitrant species.

In order to examine and understand the structural developmental and the concomitant establishment of ecosystem function processes in long-lived vegetation such as forest and woodland, it is necessary to have examples spanning the life span of the longest-lived individuals and the recruitment and maturation of their replacements. For temperate birch woodlands this can be in the order of about 50 to 70 years and 20 to 30 years for life spans and recruitment respectively, and longer, 150 to 200 years and 50 to 70 years respectively for oak woodland (Humphries, 2013a). Given that the native forest rehabilitation examples considered here are very recent in forest development terms, this 'snap-shot' in time is only representative of the early developmental stages of the long-lived woody species and excludes the recruitment and death/decay stages of many of the dominating shrub species. In this context, proper assessments can only be a matter of extrapolation and speculation without longer term evidence incorporating species' life cycles and 
replacements. To this extent, as pointed out by Norman et al. (2006) and Gravina et al. (2011), the currently used predictive criteria and short monitoring time frames are unlikely to be sufficient in the assessment of rehabilitation success.

All three of the examples examined had been restored to a landform broadly similar to the premining topography and spread with recovered topsoil. Whilst other restoration practices were not included in the examples examined, it is likely that the general principles identified in this study are applicable, although different vegetation and dynamics are involved.

\section{Species Composition}

It is evident that woody vegetation comprising several native tree and shrub species can be readily established on the former surface mine sites in the relatively benign sub-tropical conditions of south-eastern Queensland and the Mediterranean climate in the southwest of Western Australia when the topsoil is replaced. However, it has often been pointed out that the vegetation established on rehabilitated sites generally differ to varying degrees in their similarity to 'native' target assemblage types (Norman et al., 2006; Koch, 2007b; Herath et al., 2009; Doley, et al., 2012). At the three sites examined in this study, this can largely be explained simply by the fact that a mixture of species associated with several communities and non-typical species have been sown or planted. As observed by Koch (2007b), Gravina et al. (2011 and Unpublished b), and others such as Mulligan et al. (2006), the vegetation subsequently establishing over the 20 or so years of monitoring taken place usually reflects that sown and planted.

In the earlier years of rehabilitation practice it was not unusual to include exotic non-native or non-local species as a means of ensuring a vegetation cover was achieved. In more recent years, with the improvement of establishment and site preparation practices, the species composition was often a function of availability and ease of propagation and establishment. In many cases the quality and character of the reference/target vegetation types is differentiated by the presence of small shrub and ground flora (forb, grass, and fern species), as well as the main tree canopy species. Here, their presence is of importance for the development of specific rehabilitated vegetation communities and in particular for their resilience following disturbance such as fire. However, even the more recent schemes were reported to have an incomplete or sparse understory flora even though the species had been introduced (Gravina et al., 2011; Smith and Nichols, 2011; Gravina et al., Unpublished b; Neldner and Nguni, 2014). In contrast to the sand and coal sites, the over- 
and understory composition on the Huntly Mine rehabilitated areas were more complete and persisted (Koch, 2007b; Koch and Samsa, 2007).

\section{$\underline{\text { Structural Development }}$}

The time-based data examined for the mineral sands and coal mine rehabilitation showed that the trend in early structural development of the target forest and woodland was typically a dense and largely closed-scrub formation made up of a few dominant tall shrub species. As would be expected, the resulting vegetation communities, at least in the short term of 10-20 years, were notably different to the locally occurring native stands, which are unlikely to have exhibited high canopy densities during forest regeneration. In contrast, the developing stands on the more recent bauxite rehabilitation exhibited more open-shrubland and low-woodland structures which facilitated the persistence of the lower-canopy and ground flora. For example, it was observed on a visit by the Author to areas rehabilitated for 10-20 years at the Meandu Mine in September 2014 that the small-shrub and ground flora were excluded from areas of dense canopy, but occurred in areas where there had been either a failure to establish a shrub canopy or at the edges of planting such as along the forestry fire breaks.

Historically, there has been a focus on the achievement of high stem densities for compliance purposes, irrespective of the composition and structure of the target forest/woodland types. This appears to be a legacy of earlier concerns by both the practitioners and the regulators for a sufficient density of tree and tall shrub species to establish from seed for adequate erosion control, or as in the case of the coal and bauxite mines, there were sufficient trees for timber production purposes. In both the relatively benign Australian sub-tropical and Mediterranean climatic conditions, these early concerns seem not to have been realised wherever the topsoil had been replaced and good restoration practices were implemented (as establishment from seed and/or nursery planting generally readily takes place during favourable weather conditions).

In the absence of reducing sowing and planting densities or the thinning of the canopy layer, the outcome will be dense stands of woody vegetation dominated by mainly quick-growing shrubs and middle-canopy tree species (which exclude the slower-growing tree canopy and low-shrub and ground-cover structural formation species). Given that in the older schemes at the mines on North Stradbroke Island and the Meandu Mine the dominant and relatively short-lived woody species are now beginning to die back after 20 or so years, there has to be uncertainty in the predicted trajectory 
of future vegetation development in the absence of recruitment, replacement cohorts, and the low density of other tree and shrub layer species. In addition, the high fuel load of the woody stands carries a high risk of intense fires occurring, as has already occurred on North Stradbroke Island (Gravina et al., 2011;Smith and Nichols, 2011), with similar consequences as die-back through ageing.

For both North Stradbroke Island and the Meandu Mine, the actual outcome of the rehabilitated sites reported in the literature can only become evident through further and much longer term observation. The data collected so far suggests that a period of 20-30 years is not long enough where there is uncertainty of the persistency and dynamics of the vegetation being recorded. This may be despite the metrics of the predicted completion criteria having been met in the very early development of the rehabilitated stands.

For the bauxite rehabilitation, there is greater confidence given that the structural development is towards a forest formation, so much so that the agreed predictive monitoring is currently only necessary after 9 and 15 months of establishment, thereby negating further long term commitment to monitor (Grant, 2006; Koch, 2007a). However, whilst this may account for the early stages of development, the longer term ecosystem processes of replacement cohorts remains to be demonstrated as discussed further below.

\section{Attainment of Target Forest Ecosystems}

Taking the above findings for the mineral sand and coal rehabilitation schemes established some 10 to 20 years ago, the implied trajectory towards the attainment of the target forest ecosystems is not as anticipated by the adopted predictive criteria. This is because the development of the forest structure, in the short term, has 'stalled' as a scrub formation owing to the dense canopy of tall competitive shrub/small tree species. This has had the concomitant effect of excluding high-forest species as well as characteristic small shrub and ground flora associated with the respective target ecosystems. The same tendency for dominance by some species of tall shrubs has also been reported for mineral sand rehabilitation in Western Australia (Herath et al., 2009).

In contrast, the bauxite rehabilitation examples of a similar age were displaying the anticipated trajectory traits towards the attainment of the target forest ecosystems irrespective of the use of the non-structural predictive criteria (Grant, 2006). It was evident from the monitoring data and a subsequent site visit in September 2014 that a forest structure was developing with the growth and 
development of the high-forest tree species, along with the persistence of the characteristic small shrub and ground flora associated with the target ecosystems. Earlier examples of bauxite rehabilitation had seemingly exhibited similar trends as the sand and coal examples referred to above. The later bauxite rehabilitation schemes had incorporated changes in rehabilitation practice whereby sowing density of competitive shrub/small tree species was reduced or the species excluded, along with an emphasis on establishing the characteristic species (Grant, 2006; Grigg, 2012). This approach has continued with further refinements.

Latterly, as was witnessed during a site visit in August 2014, a similar approach to reducing competition and increasing the persistence of characteristic species has been adopted in the more recent rehabilitation at the Meandu Mine. Consequently, the initial structure and persistence of the initial composition at establishment is seemingly being achieved as in the bauxite rehabilitation. It appears from the review of Smith and Nichols (2011) that a similar approach is likely to have been adopted for the more recent mineral sand mine rehabilitation on North Stradbroke Island. Alternatively, intervention, in the form of burning or thinning, during the development of the forest structure and composition has been tried and deployed as a means of reducing competition and maintaining composition with varying degrees of success (Harwood and Corbett, Unpublished b; Harwood, et al., Unpublished; Grant, et al., 2007; Grigg and Grant, 2009; Gravina et al., 2011, Smith and Nichols, 2011; Grigg, 2012).

However, in all cases the attainment of the targeted composition and associated structural formation need not necessarily lead to the functional rehabilitation of the ecosystem. This requires the exhibition of not only growth and maturation, but death and decay along with recruitment and replacement of the component species as evidence of the cyclic and dynamic nature of forest ecosystems (Humphries, 2013a; Král et al., 2014). Given this fundamental characteristic of sustainable ecosystems and the time-sequences involving many decades, it is of no surprise that this evidence is unlikely to be currently available for compliance and decision-making purposes. Adopting the 'predictive' approach, evidence such as maturation of component species to seed production/clonal propagation along with the presence of seedlings/clonal spread and their growth and maturation may reduce this, but may still remain too distant in the future. Consequently, reliance will have to be based on the historical evidence for regeneration from much earlier examples of rehabilitation and this should be investigated. At present, the predictive criteria of vegetation structural formation, species recruitment, and replacement are obvious omissions (with 
respect to the rehabilitation of ecosystem function and sustainability). These matters need to be addressed wherever evidence-based restoration is applied to mine consents (Humphries, 2013b); otherwise it may be a matter of faith as has been pointed out by Powter (2014).

Finally, from the above perspective, given that insufficient time has yet lapsed for forest maturity and recruitment for community renewal, it is evident that the 'jury is still out' in respect of whether in the longer term development continues to accord with that of the Initial Floristic Composition Model (Koch, 2007b; Norman et al., 2006), rather than any other successional or ecosystem models (Humphries, 2013a).

\section{Conclusions}

Whilst only three examples were examined and have limitations in the amount of accessible information available for this paper, sufficient insight has been gleaned to provide several lessons that are likely to be of use in the planning, management, and evaluation of woody vegetation rehabilitation schemes in Australia and elsewhere.

The first and key lesson arising from the examination of monitoring data for the three examples of mine rehabilitation in Australia is that structural formation is of considerable importance in establishing the predicted trajectory of the developing forest/woodland. Yet, it is a metric that is commonly omitted from agreed monitoring schemes and their predictive criteria. As has previously been suggested, other criteria than those currently used are needed to determine if the rehabilitation is to be assessed to be achieving the specified target forest types and their ecosystems. The assessment of structural traits and species composition enables this as well as providing evidence of ecosystem function and sustainability in the form of life-cycle (age-class) composition and the concomitant replacement cohorts.

Secondly, practitioners and regulators should ensure attention is given to the initial seed and planting mixtures and densities so that they are representative of the targeted plant community compositions, and hence, ultimately their structural formations. The evidence suggests that whatever is initially sown or planted, at least in the first generation, determines the type of vegetation community establishing. Hence, consideration needs to be given whether they are 'pioneer' or 'late' forest species, native or invasive/exotic species. 
Thirdly, they should also ensure the provision for proactive intervention and management where it is evident that structural development is diverging from the target type. For example, the 'stalling' of development at the closed scrub stage (typically between 10 and 20 years owing to the short life-span of the dominant species) is indicative of the need for intervention. Intervention, and possibly repeated intervention over a 10-20 year cycle, may be necessary to adjust the initial composition and structure to attain sufficient similarity with the reference or target types as the forest develops and matures. Hence, an assumption that target types are attainable just by seeding and planting without further measures and action should be challenged. Otherwise, it is only too evident that different vegetation communities and structural formations to that intended could be the outcome.

Fourthly, the same ecological and ecosystem processes are likely to be involved irrespective of the mineral being mined and climate where the surface mining and reclamation processes are similar; such as the replacement of the pre-mining soils in a similar topographic context. The fact that the outcomes were similar in the three examples examined, suggests that vegetation structural formations (e.g., forests, grassland, heaths) might be overarching models enabling lessons, such as those discussed in this paper, to be globally applied.

\section{Acknowledgements}

Queensland University's Centre for Mined Land Rehabilitation kindly provided facilities to RNH to undertake this research whilst a Visiting Academic. Professor David Mulligan and Dr. Amanda Gravina of CLMR are thanked for their comments on the draft manuscript. Alcoa of Australia kindly provided rehabilitation data for their Huntly Mine rehabilitation, and Dr. Andrew

Grigg and Dr. Mathew Daws of Alcoa of Australia are also thanked for their comments. The interpretation of data and any errors arising are solely the Author's. 
JASMR, 2016 Volume 5 Issue 1

\section{$\underline{\text { References }}$}

Department of Environment and Heritage Protection. 2014. Guidance Resource Activities: Rehabilitation requirements for mining resource activities. Queensland Government, Brisbane.

Department of Mines and Petroleum and the Environmental Protection Agency. 2011. Guidelines for Preparing Mine Closure Plans. Government of Western Australia, Perth.

Department of Science, Information Technology, Innovation, and the Arts. 2012a. Regional Ecosystem Technical Descriptions.

https://www.ehp.qld.gov.au/ecosystems/biodiversity/regionalecosystems/technical_descriptions.html Viewed $19^{\text {th }}$ August 2014.

Department of Science, Information Technology, Innovation, and the Arts. 2012b. Assessment of BioCondition: Meandu Mine, Southeast Queensland. Brisbane.

Doley, D., P. Audet, and D.R. Mulligan. 2012. Examining the Australian context for post-mined land rehabilitation: Reconciling a paradigm for the development of natural and novel ecosystems amongst post-disturbance landscapes. Agriculture, Ecosystems and Environment 163: pp 85-93. http://dx.doi.org/10.1016/j.agee.2012.04.022.

Erskine, P.D., A.T. Fletcher, and B. Seaborn. 2013. Opportunities and constraints of functional assessment of mined land rehabilitation. In Tibbett M., A.B. Fourie and C. Digby (Eds), Proceedings of the Eighth International Conference on Mine Closure, Cornwall, England. Australian Centre for Geomechanics, Nedlands, Western Australia pp 345- 354.

Eyre, T.J., A.L. Kelly, and V.J. Nelder. 2011a. Method for the Establishment and Survey of Reference Sites for BioCondition. Version 2.0. Department of Environment and Resource Management, Biodiversity and Ecological Sciences Unit, Brisbane.

Eyre, T.J., A.L. Kelly, V.J Neldner, B.A. Wilson, D.J. Ferguson, M.J. Laidlaw, and A.J. Franks. 2011b. BioCondition: A condition assessment framework for terrestrial biodiversity in Queensland. Version 2.1. Department of Environment and Resource Management, Biodiversity and Ecological Sciences, Brisbane. 
FORSCI. Unpublished. Provisional Site Index Curves for Jarrah (Eucalyptus marginata) Growing on Rehabilitated Bauxite Mine Sites in South-Western Australia. Report, September 2012. FORSCI Pty. Ltd.

Gardner, J.H. and D.T. Bell. 2007. Bauxite mining restoration by Alcoa World Alumina Australia in Western Australia: social, political, historical, and environmental contexts. Restoration Ecology: 15, S3-S10 https://doi.org/10.1111/j.1526-100X.2007.00287.x.

Grant, C.D. 2006. State-and-Transition successional model for bauxite mining rehabilitation in the Jarrah Forest of Western Australia. Restoration Ecology: 14, 1, pp 28-37. http://dx.doi.org/10.1111/j.1526-100X.2006.00102.x.

Grant, C.D., M.A. Norman, and M.A. Smith. 2007. Fire and silvicultural management of restored bauxite mines in Western Australia. Restoration Ecology: 15 S127-S136 https://doi.org/10.1111/j.1526-100X.2007.00300.x.

Gravina, A., P. McKenna, and V. Glenn. 2011. Evaluating the success of mineral sand mine rehabilitation on North Stradbroke Island, Queensland: comparisons with reference eucalypt communities. In Arthington, A.H., T.J. Page, C.W. Rose, and S. Raghu (Eds), Proceedings of the Royal Society of Queensland, Volume 117, A Place of Sandhills: Ecology, Hydrogeomorphology and Management of Queensland's Dune Islands. Royal Society of Queensland, St Lucia pp 419-435. .

Gravina, A., P. McKenna, and P. Erskine. Unpublished a. Proposed Completion Criteria for Native Ecosystem Rehabilitation at Tarong Meandu Mine. Report to Tarong Energy Corporation Pty Ltd, September 2010. Centre for Mined Land Rehabilitation, Sustainable Minerals Institute, University of Queensland, St Lucia.

Gravina, A., V. Glenn, and P. Audet. Unpublished b. Tarong Coal Meandu Mine and Kunioon Test Pit Rehabilitation Monitoring and Compliance with EA Criteria: 2011 Assessment. Report to the Stanwell Corporation Limited, 2012. Centre for Mined Land Rehabilitation, Sustainable Minerals Institute, University of Queensland, St Lucia.

Grigg, A. 2012. Adaptive rehabilitation management and a drying climate: unique challenges for Alcoa's bauxite mine rehabilitation in southwestern Australia. In Fourie, A.B. and M. Tibbett 
(Eds), Proceedings Seventh International Seminar on Mine Closure, 25-27 ${ }^{\text {th }}$ September 2006. Australian Centre for Geomechanics, Perth pp 459-466.

Grigg, A.H. and C.D. Grant. 2009. Overstorey growth response to thinning, burning and fertiliser in 10-13-year-old rehabilitated jarrah (Eucalyptus marginata) forest after bauxite mining in south-western Australia. Australian Forestry: 72, 2, pp 80-86. http://dx.doi.org/10.1080/00049158.2009.10676293.

Harwood, M. and M. Corbett. Unpublished a. Vegetation survey of native plant communities and a chronosequence of rehabilitation age classes. In Corbett, M. and M. Harwood (Eds), Ecosystem Development Following Heavy Mineral Sand Mining on North Stradbroke Island: Assessment of rehabilitation and the development of indicators of rehabilitation success, Volume 2, Experimental Results. Report to CRL, September 2000. Centre for Mined Land Rehabilitation, University of Queensland, St Lucia. pp 2.1-2.22.

Harwood, M. and M. Corbett. Unpublished b. The influence of fire on the composition of rehabilitation communities of different ages. In Corbett, M. and M. Harwood (Eds). Ecosystem Development Following Heavy Mineral Sand Mining on North Stradbroke Island: Assessment of rehabilitation and the development of indicators of rehabilitation success, Volume 2, Experimental Results. Report to CRL, September 2000. Centre for Mined Land Rehabilitation, University of Queensland, St Lucia. pp 8.1-8.44.

Harwood, M., B. West, and G. Bradford. Unpublished. The effects of manually clearing Acacia concurrens on the development of the rehabilitation vegetation community. In Corbett, M. and M. Harwood. (Eds.). Ecosystem Development Following Heavy Mineral Sand Mining on North Stradbroke Island: Assessment of rehabilitation and the development of indicators of rehabilitation success, Volume 2, Experimental Results. Report to CRL, September 2000. Centre for Mined Land Rehabilitation, University of Queensland, St Lucia. pp 9.1-9.36.

Herath, D.N., B.B. Lamont, N.J. Enright, and B.P. Miller. 2009. Comparison of post-mine rehabilitation and natural shrubland communities in Southwestern Australia. Restoration Ecology: 17, pp 577-583. http://dx.doi.org/10.1111/j.1526-100X.2008.00464.x. 
Hopper, S.D. 2009. OCBIL theory: towards an integrated understanding of the evolution, ecology and conservation of biodiversity on old, climatically buffered, infertile landscapes. Plant Soil: 322, pp 49-86. http://dx.doi.org/10.1007/s11104-009-0068-0.

Humphries, R.N. 2013a. Understanding and delivery of the components of structure, diversity, and function in the restoration of ecosystems on mined land: working towards a practical methodology. Journal of the American Society of Mining and Reclamation, Vol. 2 Issue 2, pp 1-31. http://dx.doi.org/10.21000/JASMR13020001.

Humphries, R.N. 2013b. The requirement and implications of evidence-based restoration schemes in the United Kingdom. In Tibbett, M., A. B. Fourie, and C. Digby (Eds), Proceedings Eighth International Seminar on Mine Closure, Eden Project, Cornwall, 18-20 ${ }^{\text {th }}$ September 2013. Australian Centre for Geomechanics, Perth. pp 355-362.

Humphries, R.N. 2014. Why reinvent the wheel when there are established methodologies to aid the design and assessment of restored natural ecosystems on mined land? In Life of Mine 2014, Brisbane. Australian Institute for Mining and Metallurgy. pp 675-692.

Humphries, R.N. 2016. Extended ecosystem function analysis - the next step for mine rehabilitation appraisals. In Fourie A. B. and M. Tibbett (Eds), Proceedings Eleventh International Conference on Mine Closure, Perth, Western Australia, 15-17th March 2016. Australian Centre for Geomechanics, Perth pp 35-46.

Koch, J.M. 2007a. Alcoa's mining and restoration process in South Western Australia. Restoration Ecology: 15, S11-S16. https://doi.org/10.1111/j.1526-100X.2007.00288.X

Koch, J.M. 2007b. Restoring a jarrah forest understorey vegetation after bauxite mining in Western Australia. Restoration Ecology: 15, S26-S39. https://doi.org/10.1111/j.1526100X.2007.00290.x

Koch, J.M. and R.J. Hobbs. 2007. Synthesis: is Alcoa successfully restoring jarrah forest after bauxite mining in Western Australia? Restoration Ecology: 15, S17-S25. https://doi.org/10.1111/j.1526-100X.2007.00289.x

Koch, J.M. and G.P. Samsa. 2007. Restoring jarrah forest trees after bauxite mining in Western Australia. Restoration Ecology: 15, S137-144. https://doi.org/10.1111/j.1526100X.2007.00301.X 
Král, K., S.M. McMahon, D. Janík, D. Adam, and T. Vrška T. 2014. Patch mosaic development stages in central European natural forests along vegetation gradient. Forest Ecology and Management: 330, pp 17-28. http://dx.doi.org/10.1016/j.foreco.2014.06.034.

Lacy, H.W.B., T. File, and B. Biggs. 2008. Ecosystem Function Analysis: Measuring and monitoring for mine closure and completion in Australia and abroad - 1994 to 2008. In A.B. Fouries, M. Tibbett, I.M. Weiersbye, and P.J. Dye (Eds). Third International Conference on Mine Closure, Johannesburg, South Africa, October 2008. Australian Centre for Geomechanics, Perth.

Mulligan, D.R., M J. Gillespie, A.J. Gravina, and N.A. Curry. 2006. An Assessment of Direct Revegetation Strategy on the Tailings Storage Facility at Kidston Gold Mine, North Queensland, Australia. In Fourie, A.B. and M. Tibbett (Eds.), Proceedings First International Seminar on Mine Closure, 13-15 ${ }^{\text {th }}$ September 2006. Australian Centre for Geomechanics, Perth. pp 71-381.

Neldner, V.J. and M. Ngugi. 2014. Application of the BioCondition assessment framework to mine rehabilitation. Ecological Management and Restoration: 15, 2, pp 158-161. http://dx.doi.org/10.1111/emr.12102.

Norman, M.A., J.M. Koch, C.D. Grant, T.K. Morland, and S.C. Ward. 2006. Vegetation succession after bauxite mining in Western Australia. Restoration Ecology: 14, 2, pp 278-288. http://dx.doi.org/10.1111/j.1526-100X.2006.00130.x.

Powter, C. 2014. Faith-based reclamation. Canadian Reclamation: 14, 2, pp 4-5.

Smith, P. and O. Nichols. 2011. Development and assessment of rehabilitation criteria for high dune mineral sands mining on North Stradbroke Island. In Arthington, A.H., T.J. Page, C.W. Rose, and S. Raghu (Eds.), Proceedings of the Royal Society of Queensland, Volume 117, A Place of Sandhills: Ecology, Hydrogeomorphology and Management of Queensland's Dune Islands. Royal Society of Queensland, St Lucia. pp 347-363.

Specht, R.L, 2011. Plant communities of North Stradbroke Island: development of structure and species richness. In Arthington, A.H., T.J. Page, C.W. Rose, and S. Raghu (Eds.), Proceedings of the Royal Society of Queensland, Volume 117, A Place of Sandhills: Ecology, 
Hydrogeomorphology and Management of Queensland's Dune Islands. Royal Society of Queensland, St Lucia. pp 181-191.

Stephens, K. 2011. Comparative floristic analysis of vegetation on the dune islands of south-east Queensland. In Arthington, A.H., T.J. Page, C W. Rose, and S. Raghu (Eds), Proceedings of the Royal Society of Queensland, Volume 117, A Place of Sandhills: Ecology, Hydrogeomorphology and Management of Queensland's Dune Islands. Royal Society of Queensland, St Lucia. pp 141-180. .

Stephens, K. and R. Dowling. 2002. Terrestrial Vegetation Survey: CRL IBIS Mine Study. Report for the Environmental Protection Agency, Queensland Government. Queensland Herbarium, Brisbane.

Tongway, D.J. and J.A. Ludwig. 2006. Assessment of landscape function as an information source for mine closure. In Fourie, A. B., and M. Tibbett (Eds.), Proceedings First International Seminar on Mine Closure, 13-15 ${ }^{\text {th }}$ September 2006. Australian Centre for Geomechanics, Perth. pp 21-29. 